\title{
EFFECT OF INVESTMENT CLIMATE ON SMALL AND MEDIUM SCALE ENTERPRISES GROWTH IN MAKURDI METROPOLIS, BENUE STATE NIGERIA.
}

\author{
Adamu Garba ${ }^{1 *}$ \\ *l Department of Business Administration, Nasarawa State University, Keffi, Nasarawa State
}

*Corresponding Author: -

\begin{abstract}
: -
This study evaluated the effect of investment climate on Small and Medium Scale Enterprises growth in Makurdi Metropolis. The study was anchored on The Neoclassical Approach, Financial Growth Theory and Theory of diffusion of innovation. The researcher used both primary and secondary sources from a sample of 250 respondents obtained by the use of a well-structured questionnaire from the study areas. The demographic data collected were analyzed using descriptive statistics such as frequency, simple percentage and the relationship between the variables of the study were analyzed using multiple linear regression analysis. The hypotheses of the study were tested using the probability value of the estimates. The result of the regression analysis indicates that a negative relationship exist between access to credit (ACTC) and Small and Medium Scale Enterprises growth in Makurdi Metropolis Nigeria (SGT) and the relationship is not statistically significant $(p>0.05)$ and not in line with a priori expectation. Power supply $(P W S P)$ was positively related to Small and Medium Scale Enterprises Growth in Makurdi Metropolis Nigeria (SGT) and the relationship is statistically significant $(p<0.05)$ and in line with a priori expectation. A positive relationship exist between Information and Communication Technology (ICT) and Small and Medium Scale Enterprises Growth in Makurdi Metropolis Nigeria $(S G T)$ and the relationship is statistically significant $(p<0.05)$ and in line with a priori expectation. It was concluded that for this growth to be achieved, the climate of investment must be addressed and made favourable for business start-up and growth. It was recommended that government should effectively regulate the power sector as there are still lingering challenges with billings, tariffs and metering processes after privatization. To ameliorate the problem faced by SMEs in the study area, government can create hubs for SMEs in the study area and provide them with adequate electricity or develop renewable energy such as solar energy to improve entrepreneurs' access and growth.
\end{abstract}

Keywords: Investment, Climate, SMEs, Growth, Benue, Nigeria.

\section{(우 $\circledast$ (1)}




\subsection{INTRODUCTION}

The investment climate can be understood as the set of factors in a given location that shape firms' incentives and opportunities to invest, grow and create jobs. Some of these factors are costs; others are risks; still others are the competitive forces in the economy. Together, they determine the vibrancy and reach of private sector firms in the economy. A strong investment climate is not a serendipitous occurrence: it is the result of country authorities formulating, implementing and enforcing an appropriate set of policies (Dollar et al., 2005). There are, however, other variations as to what defines an investment climate and profound disagreement as to which social, political or economic factors have prevented the development of a strong investment climate. The World Bank (2005) asserts that a good investment climate is not just about generating profits for firms but also about improving outcomes for society including through its impact on job creation, lower prices, and broadening the tax base.

The purpose for investment climate is to provide a set of solid foundations establishing the priorities and best ways, which can help business governance structure, reach their goals, while balancing out the social, economic and environmental demands for economic growth and development. It is therefore pertinent to note that a friendly investment climate begets a vibrant economy and subsequently economic growth that eventually lead to economic development of any nation. The World Bank (2005) defines the investment climate as a set of location-specific factors shaping the opportunities and incentives for firms to invest productively, create jobs, and expand (including: stability and security, regulation and taxation, finance and infrastructure, and workers and labour markets). Reforms to the investment climate can be logically understood to mean a set of policy adjustments aimed at improving the location specific factors shaping the opportunities and incentives for firms to invest productively, expand and create jobs. The specific sets of factors to be adjusted are often identified through systematic and standardized assessments of the investment climates prevalent in different countries. The term investment climate, though broadly defined, includes a country's unique attributes, or "geography" (climate, endowments of natural resources, distance from important markets, and so on), as well as the state of its infrastructure, economic and social policies, institutions, and governance stability.

Often the literature fails to disaggregate the concept of investment climate. A strong investment climate for one firm is not necessarily a strong investment climate for another and a generalised concept of investment climate can be inaccurate. Dollar et al (2005), for example use a series of interviews to produce indicators which assess the investment climate. These interviews are all, however, with firms in the garment industry and the resulting indicators may not produce a true assessment of the wider investment climate. Mills and Fan (2006) note that during the post-conflict period it is the telecoms sector which seems to grow first followed by energy, then transport with water and sanitation developing much later. This suggests that the investment climate in post-conflict situations would be different for different sectors. Investment in one type of industry can discourage other types of investment. This is particularly the case concerning investment associated with the extraction of natural resources as opposed to other types of investment. Large resource exports can overvalue the exchange rate, which can undermine growth of other industries especially those dependent on exports (Moran, 2006). The presence of natural resources can profoundly distort the political economy of a country and foster corruption and rent-seeking activities

Small and Medium Enterprises (SMEs) account for over $90 \%$ of business outfits in Nigeria. This reflects also in about a half of output and export shares of the country. However, many of the firms in the country are still in the primary stage of development. When managed effectively and efficiently, SMEs will serve as the pivot of economic growth in Africa. This is because; they have the potentials for job creation, income generation, sharing of technological know-how and poverty reduction. Perhaps due to other national income sources like oil and water, most states of Nigeria have over the last three decades, gradually neglected the SMEs sector. This neglect has reflected in arithmetic economic growth statistics, increase in structural unemployment and deepening of poverty levels in the country. Examples around show that SMEs have played significant roles in the economies of OECD and APEC countries. The issue is not whether there are SMEs in Nigeria, rather, there is need to evaluate how own-country investment policies and reforms have impacted the progress of SMEs in the three states under review.

SMEs are flexible and thus, respond quickly to evolving economic changes. They use more labor than capital intensive; hence, they attract lower capital cost in job creation. Lagos, Abuja and Port Harcourt are characteristically similar, particularly as it concerns the operation of SMEs. While geographical differences cannot be denied and aside from stateown initiatives, the policy structure and the business climate of SMEs are central to the Nigerian state. This will aid in policy construction to address the issue of improving the private sector in Nigeria. The basis for comparison and policy integration was applied by surveying Abuja, the administrative capital of the Nigeria, Lagos, the economic capital of Nigeria, which provided business concentration and Port Harcourt an oil rich state. This survey encapsulates the investment climate in each region, which is driven by local and national investment reforms. In all, a favorable investment climate will encourage private participation, which will reflect increase taxes, which will be used to cater for the welfare of the poor.

In Nigeria, SMEs have not performed commendably well as they have not adequately played the expected significant role in the economic growth of the nation (Taiwo \& Falohun, 2016). Also, there is inadequacy in the performance of the SMEs role in influencing apprentice training so as to speed up employment creation as well as to alleviate poverty so as to promote Nigerian economic development and growth (Osotimehin, Jegede, Akinlabi \& Olajide, 2012). Also, Muktar, Gambo, and Mukhtar (2015) posited that there is a high preference among consumers for imported goods and the country engages in more of importation than exportation. Okpara (2011) identified factors such as insufficient financial support, 
corruption, poor management, poor infrastructure, poor managerial skills, and low demand for products and services as the factors which brings about low performance in the SME sector.

It is an established fact globally that the small and medium enterprises (SMEs) sector is a key engine to economic growth and development. This sector is responsible for most of the advances in new products and process, provides most of the employment opportunities and is also a key indicator of the overall performance of an economy (Asaju, 2010). The contribution of small and medium enterprises (SMEs) to economic growth and sustainable development is globally acknowledged (CBN, 2014). There is an increasing recognition of its pivotal role in employment generation, income redistribution and wealth creation (NISER, 2014). The small and medium enterprises (SMEs) represent about 87 per cent of all firms operating in Nigeria (USAID, 2015). Non-farm micro, small and medium enterprises account for over 25 per cent of total employment and 20 percent of the GDP (SMEDAN, 2017) compared to the cases of countries like Indonesia, Thailand and India where Micro, Small and Medium Enterprises (MSMEs) contribute almost 40 percent of the GDP (IFC, 2012).

According to Lyons, Brown and Msoka, (2014), the investment climate for private sector is the conditions necessary for domestic business and entrepreneurs to operate and the conditions that facilitate international trade and private investment into a country. This study examines three proxies of investment climate and how they affect the growth of small and medium scale enterprises in Benue State, Nigeria. These proxies are; access to finance, the availability of information and communication technology and power supply.

Access to finance is one of the most critical factors that slow the growth of small and medium scale enterprises in the country. This has necessitated the setting up of various programmes by present and past governments in Nigeria towards addressing the low access to finance of entrepreneurs in Nigeria. Over the years, government has put in place several financial programmes to promote micro enterprises. Two of these are the rural banking scheme (RBS) and community banking that was introduced into the county in 1977 and 1990 respectively. They were established to encourage rural banking system and bring nearer to the poor people the banking services (Nzotta, 2004) with this, it was hoped that banking habits would be imbibed and thus, encourage savings mobilization and credit expansion. Unfortunately these schemes could not live up to expectations and consequently, microfinance banking system was launched in Nigeria, in December 15, 2005, but started full operations in 2007, aimed all extending credits and providing other vital financial services to low income groups, encouraging and sustaining the growth of micro enterprises in the country.

There is a consensus among state policy makers, development economists as well as international development partners that small and medium enterprises (SMEs) are a potent driving force for their industrial growth and indeed, overall economic development (Owualah and Obokoh, 2008). SMEs are also touted as a veritable tool for attaining one of the seventeen Sustainable Development Goals (SDGs) of eradicating extreme poverty in the latter, poverty is caused by inadequate incomes and incomes result from employment which SMEs are widely known to provide (Owualah and Obokoh, 2008). The economy of any given country is judged by the quality of her economic indicators especially the growth of the small and medium enterprises (SMEs) that is expected to be backed up with a supportive enabling environment (investment climate) that is devoid of frustration so as to achieve a desired target for development.

Despite these huge investments, the Small and Medium Scale Enterprises in Benue State, Nigeria still performs at dismay level; it is therefore doubtful if the investment climates in the country have yielded very desirable results. The main objective of this study is to examine the effect of investment climate on Small and Medium Scale Enterprises growth in Benue State. The specific objectives of the study are to: examine the effect of access to credit on Small and Medium Scale Enterprises growth in Benue State, determine the effect of Information and Communication Technology on Small and Medium Scale Enterprises growth in Benue State and determine the effect of power supply on Small and Medium Scale Enterprises growth in Benue State.

\subsection{REVIEW OF RELATED LITERATURE Conceptual Framework Investment climate}

The term investment climate, broadly defined, includes a country's unique attributes, or "geography" (climate, endowments of natural resources, distance from important markets, and so on), as well as the state of its infrastructure, economic and social policies, institutions, and governance stability. A narrower definition of investment climate is that which focuses on the endogenous determinants of investment. For example, Gans and Stern (2000) notes that it is "the policy, institutional, and behavioral environment, present and expected, that influences the returns, and risks, associated with investment." This definition, in its reduced form, can be further explained to include economic incentives, which are shaped by macroeconomic and regulatory policies and public administrative procedures and incentives embodied in institutional arrangements such as security of property rights and rule of law and governance stability.

Hampel-Milagrosa et al, (2015) define investment climate as 'a country's business regulations and legal/regulatory framework to public infrastructure, national and private banks and government institutions, and support for the interrelationship and dialogue between public entities and firms, markets and entrepreneurs'. Aligning with HampelMilagrosa et al, Bowen, Cochrane and Fankhauser (2012) agrees with the above definition but adds that investment climate further 'includes infrastructure (power and transportation), ICT, education and health, and a broad concept of good governance and rule of law'. The term is also now used to refer to the international investment climate for private sector development, meaning global trade and investment regimes and the macroeconomic environment (ODA, 2018). Lyons et al. (2014) also defines the investment climate for private sector as 'the conditions necessary for domestic 
business and entrepreneurs to operate and the conditions that facilitate international trade and private investment into a country'.

Early efforts were initiated to understand what the investment climate is; the set of location-specific factors shaping the opportunities and incentives for firms to invest productively, create jobs, and expand focused on broad indicators of country risk, often based on surveys of international experts and usually resulting in a single score for each country. In an effort to break through these limits, researchers began a few years ago to search for micro-level evidence on the quality of a location's investment climate and for ways to trace the climate's impact on the investment decisions and growth and performance of firms after all, higher productivity holds the key to boosting growth in the developing world. The World Development Report 2005 (WDR) is the first to bring together insights from two World Bank initiatives; the Investment Climate Surveys and the Doing Business. The surveys provided growing evidence that demonstrates the fundamental role that an improved investment climate has in encouraging growth and poverty reduction, for example, China lifted 400 million people out of poverty, India doubled its growth rate, and Uganda grew at eight times the average of other subSaharan African countries through investment climate reforms.

In other words, the concept of investment climate has two key dimensions; the policy or regulatory framework and market functioning or firm performance. The policy or regulatory framework deals with the "business environment"( it spans international, national and sector/or industry level policies and institutions, including trade agreements and trade policy as well as domestic industrial policy reform), while the firm performance or market functioning level include structures key for the private sector to develop and operate. For example those aimed at facilitating production and distribution of goods and services, addressing market failures and imperfections and integrating all actors into markets, including small and medium-sized enterprises (SMEs). These ones are very common with developing countries and include, among others; Infrastructure - comprising physical infrastructure interventions directly related to private sector operations, such as building roads to facilitate market access and strengthening supply chains; access to finance; this include support to financial intermediaries, both formal and informal, such as support to expand access to financial services for micro, small and medium-sized enterprises (MSMEs) in rural areas and Labour force - comprising social infrastructure interventions directly related to private sector development, such as vocational training or managerial and technical capacity building aimed at increasing the skills and employability of the local labour force, information communication technology and the health care services for the labour force.

\section{Small and Medium Enterprises (SMEs)}

The term 'small and medium enterprises' describes group of business organisations that are especially heterogeneous as they embrace a broad varied forms ranging from hotels, manufacturing industries, agriculture, restaurants, computer software firms and small machine shops among many others (Asaolu, Oladoyin, \& Oladele, 2005). According to OECD (2004), the sole aim of the introduction of the concept small and medium enterprises into development scenery was to perk up trade and industrialization in the today developed nations. The small and medium enterprise definitions are drawn from each country based on the policies, agencies, programs and institutions, and the role of SMEs in the economy (Abdullah, 2000; Etuk, Etuk \& Baghebo, 2014). The survival of SMEs has been long recognized crucial to the growth of any economy in the world (Oba \& Onuoha, 2013). Existing reports show that SMEs occupies $80 \%$ of the global economy (Nnanna, 2002). The categorization of business enterprises into large, medium or small scale has tagged along diverse decisive factor such as the total employment, revenue, assets or investment. According to existing studies, the characterization of SMEs varies in different economies although the core concept is similar (Adeyemi 2011; Ajayi, 2000; Ogechukwu, Oboreh, Umokoro \& Uche, 2013). According to Okonkwo and Obidike (2016), the meaning given to small and medium enterprises differs in accordance with country, schools, context, scholars and author. In some countries, SMEs are defined in relation to their yearly turnover and number of staff. In other countries, SMEs are defined in term of the industry and nature of businesses (Ibrahim, 2015).

Obafemi Awolowo University, Ile- Ife Centre for Industrial Research and Development (CIRD) classified small scale business as an enterprise which has a working capital base not below and not higher than \#250,000 and employing not more than 50 workers on full-time basis. In 2005, the credit guiding principle to the commercial banks by the Central Bank of Nigeria (CBN) classified small scale enterprises as business whose annual turnover is below and not higher than \#500,000, while the Merchant banks were to considered businesses with capital investment less than \#2,000,000 (the cost of land not included) or turnover up to but not higher than 5million Naira as small scale businesses (Solomon, 2011). The Federal Ministry of Commerce and Industries cited in Olabisi, Olagbemi, and Atere (2011) classified SMEs as a firm whose total investment (with the exclusion of the cost of land, however with capital included) is close to \#750,000 and the maximum number of 50 persons as employees.

According to National Council of Industries (2009), small and medium scale enterprises are business enterprises whose overall costs with land excluded is \#200,000,000 or less. The National Council of Industry (2001) defined small and medium enterprises as businesses with between 11 and 100 employees or a total cost of N50 million or less, together with working capital and exclusive of the cost of land. While, medium Scale Enterprise is an enterprise with a labour size of between 101-300 personnel or a total cost of over N50 million but not higher than N200 million, together with working capital but without including the cost of land (Aremu and Adeyemi 2011). The Third National Development plan in Nigeria described SME as a business that employs not up to ten workers and the asset investment did not go beyond \#600,000 (Ogechukwu, 2011). 


\section{Growth of Small and Medium Scale Enterprises}

Small and medium scale enterprises growth can be defined as the process of improving on the capacity and ability of a firm to succeed (Shimer, 2012). It can be realized by either boosting the top line revenue base of the business essentially with greater market sales or income from offer of services also known as service income. It can also be the ability of the firm to increase in profitability through minimization of product costs and others so associated therein. The ability of the firm to employ more people shows strength and can be liken to growth. When a business sells more products, generate more revenue, employ more people and cuts cost, then it is considered to be growing. The firm usually strategizes to achieve this since it cannot be realized by happenstance. The strategy so adopted must be aimed at winning larger market share, even at the expense of short term earnings. There are basically four strategies usually adopted; market development, market penetration, product development and business diversification (Altenburg and Von, 2006).

It is evident from the literature that not all small businesses are growth oriented and for certain firms' growth is not a voluntary choice (Masurel and Montfort, 2016). An empirical study of SMEs growth pattern by Kolvereid and Bullvag (2016) concludes that growth intentions may be used to predict actual growth, that past intentions are related to later intentions, and that change in growth intentions are associated with changes in growth patterns. Arbaurgh and Sexton (1996) provide empirical evidence that most new firms do not grow into large ones and that there is no relationship between the age of a firm and its size. Chaston and Mangles (2017) opine that there is no single strategy to firm growth. Hence, the probability of achieving growth is increased by avoiding excessive emphasis on single-strategy transformation initiatives, and by giving different capabilities priority depending upon the development stage of the firm. They identify three factors that can limit the growth of small business; namely ability, need and opportunity. Kolvereid (2016) concluded that small business entrepreneurs who want their firms to grow start their business in order to achieve just that. The process of mutual adjustment between proprietors and their employees was identified by Goffee and Scase (2015) as a major limiting factor of small business growth. Crises in small high tech firms is usually caused by poor financial records, weak general management, product competition, diversification and acquisition, changing capital demand, high overhead structure, manufacturing and operating problems, cancelation or delay of major contracts, poor marketing and price competition.

When a firm is growing, it ensures the survival of the firm, business survival therefore is the ability to manage and stay in business (Altenburg and Eckhardt, 2006). In other words, it is the act of continuing with day-to-day business activity without necessarily been overwhelmed by interruptions. Normally, a business undergoes several challenges which may include; intense competition; recession in the general economy; natural factors or even hostile government policy (Altenburg and Von, 2016). In business just like any aspect of life, you must use good times to plan for the bad day in order to stay in business. Business survival has direct correlation with the aims and objectives of setting up the business, including the expansion plan and business growth. Business survival entails not only managing to stay in business but stay and achieve the objectives of setting up the business and its plan (Adom, 2011).

\section{Relationship between Investment Climate and Small and Medium Scale Enterprises growth.}

A good investment climate is one that benefits everyone in two dimensions. First, it serves society as a whole, rather than just firms, including through its impact on job creation, lower prices, and broadening the tax base. Second, it embraces all firms, not just large or influential firms. Early efforts were initiated to understand what the investment climate is; the set of locationspecific factors shaping the opportunities and incentives for firms to invest productively, create jobs, and expand focused on broad indicators of country risk, often based on surveys of international experts and usually resulting in a single score for each country. In an effort to break through these limits, researchers began a few years ago to search for micro-level evidence on the quality of a location's investment climate and for ways to trace the climate's impact on the investment decisions and growth and performance of firms after all, higher productivity holds the key to boosting growth in the developing world.

According to Altenburg and Eckhardt (2006), the growth of small and medium scale enterprises is affected by investment climate. A business undergoes several challenges which may include; intense competition; recession in the general economy; natural factors or even hostile government policy (Altenburg and Von, 2006). In business just like any aspect of life, you must use good times to plan for the bad day in order to stay in business. Business growth and survival has direct correlation with the aims and objectives of setting up the business, including the expansion plan and business growth. In aligning with Altenburg and Von (2006), a growing literature is developing on the barriers those SMEs particularly in Sub Saharan Africa face to their operation and growth. In particular, there is evidence of a gap in the access to and use of finance by SMEs and this is seen as a major bottleneck for the emergence and growth of these enterprises in Africa (Beck and Cull, 2014).

\section{Theoretical Framework}

\section{The Neoclassical Approach}

Proponents of the neoclassical approach to the business-enabling environment assume that most factor markets work reasonably well without government intervention if property rights and competition are guaranteed. Such interventions are in most cases considered less efficient than marketbased solutions, and it is stressed that many government interventions in fact hamper private sector development. Measures to improve the businessenabling environment consequently focus on deregulation and the good functioning of markets, with only a limited role assigned to the public sector in a few areas where market failure is most obvious. Within the neoclassical approach a distinction could be drawn 
between "regulatory business environment" and the "investment climate". Proponents of this approach do not take characteristics and motives of the entrepreneur into account. Instead, the distinguishing attribute of informal firms is nonregistration. It is assumed that the informal economy is comprised of enterprises that operate informally because the costs, time and effort of formal registration are too high (see De Soto 1989; and Palmade \& Anayiotos 2005).

The "regulatory business environment" covers regulations that immediately affect businesses through the costs of compliance. These are composed of direct costs, such as license fees, and indirect costs resulting from, often unnecessary, transactions. The latter include transaction costs arising from the time that has to be spent in obtaining a licence as well as increasing costs stemming from inappropriate government regulations that make contract enforcement or the hiring and firing of workers unnecessarily complicated and costly. The costs of the regulatory business environment are most prominently analysed in the Doing Business series published by World Bank/IFC on an annual basis since 2004. The 2007 edition (World Bank/IFC 2007) measures the costs and time associated with complying with 10 types of regulations: starting a business, employing workers, getting credit, enforcing contracts, closing a business, registering property, dealing with licences, protecting investors, paying taxes, and trading across borders. The emphasis on easing regulations and providing property rights was inspired by the works of De Soto $(1989,2000)$ as well as by reform experiences in Eastern Europe. Some of the most influential proponents of the regulatory business environment claim that such reforms are not only appropriate to unleash private sector development and growth but that they immediately benefit the poor more than proportionally because "heavy regulation and weak property rights exclude the poor from doing business" (see World Bank/IFC 2005; Klein \&Hadjimichael 2003; Klein 2006; and Klapper 2006). The theory anchored the research study because it covered the regulatory framework for investment climate and also emphasized business growth and development hence the theory is adopted for the study.

\section{Empirical Review}

Fjose, Grunfeld and Green (2010) carried out a study using firm level data on 70,000 enterprises in 107 countries; the study finds important effects of access to finance, business regulations, corruption, and to a lesser extent, infrastructure bottlenecks in explaining patterns of growth at the firm level using descriptive survey design. The study focused on how the impact of the investment climate varies across sizes of firms. The differences across size categories come from two sources. First, objective conditions of the business environment do vary systematically by firm types. Micro and small firms have less access to formal finance, pay more in bribes than do larger firms, and face greater interruptions in infrastructure services. Larger firms spend significantly more time dealing with officials and red tape. Second, even controlling for these differences in objective conditions, there is evidence of significant non-linearity in their impact on employment growth. The results suggest strong composition effects: A weak business environment shifts downward the size distribution of firms. In the case of finance and business regulations this occurs by reducing the growth of all firms, particularly micro and small firms. On the other hand, corruption and poor access to infrastructure reduce growth by affecting the productivity of medium size and large firms. With significant differences between firms with less than 10 employees and SMEs, these results indicate significant reforms are needed to spur micro firms to grow into the ranks of the SMEs.

Runyan (2006) carried out a study on firm growth and investment climate in developing countries. The researcher assessed the firm productive performances in five Middle East and North African (MENA) economies and eight manufacturing industries are compared to those in 17 other developing countries. The findings of the study show that, although the broad picture hides some heterogeneity, enterprises in MENA often performed inadequately compared to MENA status of middleincome economies, with the exception of Morocco and, to some extent, Saudi Arabia. Firm competitiveness is a more constant constraint, with a unit labor cost higher than in most competitor countries, as well as investment climate (enabling environment) deficiencies. The empirical analysis also points out how Investment Climate matters for firm growth through the quality of infrastructure, the experience and education of the labor force, the cost and access to financing, and different dimensions of the government-business relationship. These findings bear important policy implications by showing which dimensions of the Investment Climate in which industry could help manufacturing in MENA to be more competitive in the globalization context and generate jobs. The study recommended reforms in the investment climate factors in line with prevailing economic circumstances in such countries.

Okech et al. (1995) conducted a study on 16 financial institutions to determine the demand and supply of credit to the SMEs sector in Kenya. The study adopted descriptive survey methodology. The study revealed that the demand and supply for credit have been on the increase since 1991. It also revealed that the demand has only been met by 16 percent of what is required. The study also revealed that although financial institutions lend to prime borrowers with collateral security. The study therefore recommended that financial institutions should increase their lending to SMEs with softer conditions for collateral. The study adopted survey design methodology using SPSS statistical method to analyze data. Beck and Maksomovic (2002) carried out a study to examine how financial constraints affect firms of different sizes. Their study of 4,000 firms in 54 counties offers evidence that large firms internalize many of the capital allocation functions carried out by financial markets and financial intermediaries. The study recommended that systems that helps relax these constraints for small entrepreneurs will be most beneficial for SMEs. The World Development Report (World Bank, 2002) further affirm the result of this study where it indicates that small firms obtain only 30 percent of their financing from external sources, whereas large firms meet up to 48 percent of their financing needs through external financing.

Barnes (2011) carried out a study to examine the impact of continuing clients and new clients of Zambuko trust as well as program drop outs and a comparison group of non-participants in Zimbabwe. The comparison group was comprised of entrepreneurs who met Zamuko eligibility requirements including that they had owned an enterprise for at least six 
months. The results Showed benefits of repeated borrowing with only 22 percent of continuing clients earning below a dollar day versus 40 percent of non-clients and 42 percent of incoming clients. However, while the income of continuing clients was significantly higher in 1997 than the income of other groups, by 1999 the difference was no longer statistically significant though continuing clients still earned the most. This study proves that the age of a firm does not significantly affect its borrowing capacity.

Ebaidalla (2014) carried out a study on the Effect of ICTs on SMEs growth in Sub Saharan Africa (SSA): A Panel Data Analysis1with the aim to investigate the impact of Information and Communication Technologies (ICTs) on SMEs growth in the SubSaharan African (SSA) during the period 1995-2010. The study employs a dynamic panel data method for a sample of 30 SSA countries, measuring the ICT facilities by mobile cellular subscriptions and the number of internet users. The empirical results show that mobile subscriptions have a negative and significant effect on SMEs in Sub Saharan Africa countries, implying that communications boom in the last decades has promoted the SME growth. The impact of internet is found to be negative but it is not significant, confirming the weakness of internet infrastructure in SSA. To improve the SME performance in SSA, the paper recommended that the ICT facilities should be utilized effectively to enhance the operations of SMEs both in performance and cost reduction. In addition, private and foreign direct investment in ICTs should be expanded taking into account the needs of SMEs.

Mustapha and Abdullahi (2015) did a study on The Role of Information and Communication Technology (ICT) in firm productivity in the Developing World. The findings of the study reveal that Information and communication technology (ICT) plays an important role in firm operations such that it becomes indispensable in the contemporary world. The use of information and communication technology (ICT) has become integral part of our life in such a way that it is inevitable in every aspect of human Endeavour ranging from production to sales, social needs, commercial needs and above all security needs. As part of human capacity building many ICT centers employ youth to manned the centers sometimes twenty four hours daily serving customers in the developing world. The ICT center in the developing world is now becoming center of innovation and research in new products and production methods. The methodology adopted was the survey method.

\subsection{RESEARCH METHODOLOGY}

This study adopted the survey research design using primary data from purposively selected Small and Medium Scale Enterprises (SMEs) from the three geopolitical zones in Benue namely; Makurdi, Otukpo and Katsina Ala. Two hundred and fifty (250) SMEs were studied from the three geopolitical zones using the managers of each of the SMEs to gather information on the subject matter of the study. The data for the study was collected using questionnaire, coded and analyzed using computerbased Statistical Package for Social Sciences (SPSS version 20.0 for Microsoft Windows). The validity and the reliability of the instrument was established using the factor analysis. It was established that the instrument is valid and reliable as the validity score that considered Kaiser-Meyer-Olkin (KMO) and Bartlett's Test of Sphericity is above the threshold and the Cronbach Alpha Coefficient for reliability is above 0.7. The Ordinary Least Square regression (OLS) analysis was used to assess the nature and degree of relationship between the dependent variable and a set of independent or predictor variables. However, the probability value o the estimates will be used to test the 3 hypotheses of this study.

Decision rule: The following decision rules were adopted for accepting or rejecting hypotheses: If the probability value of $b_{i}\left[p\left(\mathrm{~b}_{\mathrm{i}}\right)>\right.$ critical value $]$ we accept the null hypothesis, that is, we accept that the estimate $\mathrm{b}_{\mathrm{i}}$ is not statistically significant at the $5 \%$ level of significance. If the probability value of $b_{i}\left[p\left(b_{\mathrm{i}}\right)<\right.$ critical value] we reject the null hypothesis, in other words, that is, we accept that the estimate $b_{1}$ is statistically significant at the $5 \%$ level of significance.

\section{Model Specification}

The model specification for the analysis is as follows: The general regression equation states that:

$$
Y_{i}=\beta_{o}+\beta_{1} X_{1}+\beta_{2} X_{2}+\beta_{3} X_{3}+U-(1)
$$

Where $Y_{i}=$ dependent

variable (financial performance measure)

$\beta_{o} \quad=\quad$ the intercept term

$X_{i t}=$ independent variable

$\beta_{1}, \beta_{2} \beta_{3}=\quad$ Regression coefficient

$\mathrm{U}=$ error term

The functional relationship is represented in a model form as follows:

$$
\mathrm{SGT}=f(\mathrm{ACTC}, \mathrm{PWSP}, \mathrm{ICT})-
$$

Where,

SGT = Small and Medium Scale

Enterprises Growth

ACTC $=$ Access to Capital, Initial Public Offer 
The model is written in explicit form and it reflects the dependent variable and the independent variables for the study with the error term.

$$
\mathrm{SGT}=\beta_{0}+\beta_{1} \mathrm{ACTC}+\beta_{2} \mathrm{PWSP}+\beta_{3} \mathrm{ICT}+\mu_{\mathrm{it}^{-}} \quad-\quad-\quad-\quad-\quad \text { - } \quad \text { (3) }
$$

Where:

$\begin{array}{ll}\beta 0 & =\text { the intercept term } \\ \beta 1-\beta 3 & =\text { Regression coefficients } \\ \mu_{\mathrm{it}} & =\text { Stochastic error terms }\end{array}$

\subsection{RESULTS AND DISCUSSION}

$\left(\boldsymbol{X}_{\mathbf{1}}\right)=$ Access to credit; a priori expectation is positive

$\left(\boldsymbol{X}_{2}\right)=$ Power Supply; a priori expectation is positive

$\left(\boldsymbol{X}_{\mathbf{3}}\right)=$ Information Communication and Technology; a priori expectation is positive

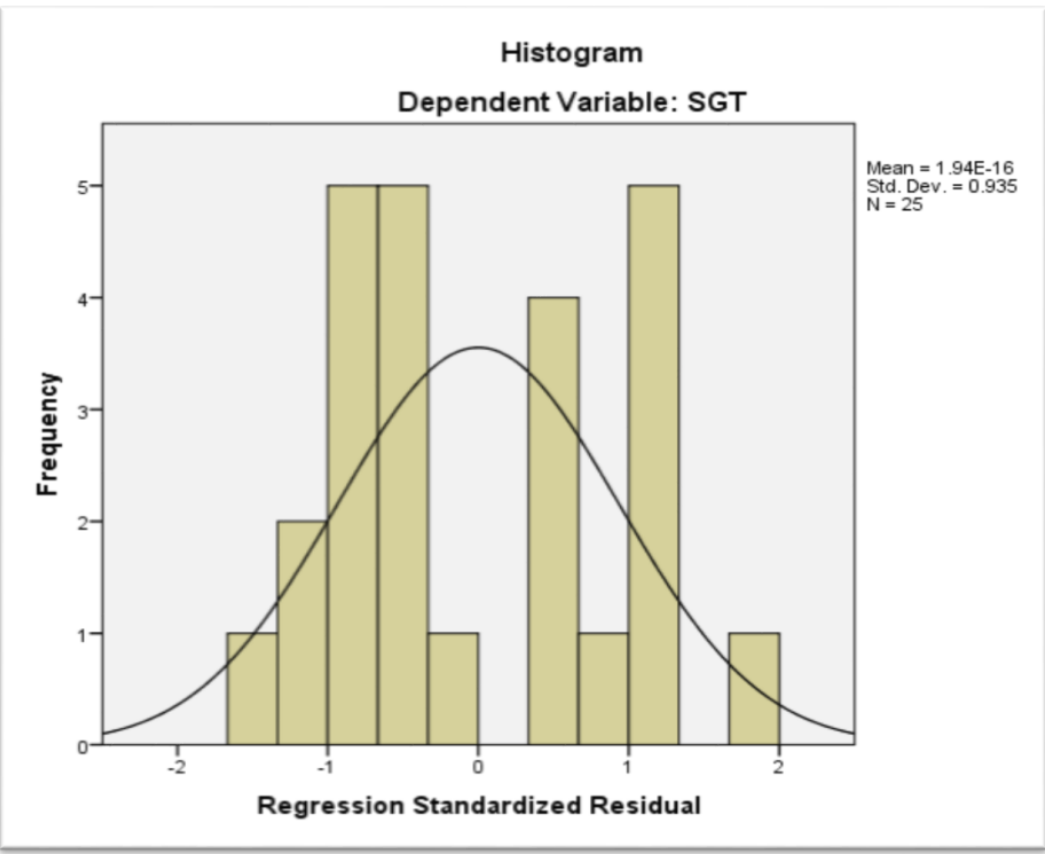

Figure 1: Regression Standardized Residual

Figure 1 above shows a histogram of the residuals with a normal curve superimposed. The residuals look close to normal, implying a normal distribution of data. Here is a plot of the residuals versus predicted dependent variable of Small and Medium Scale Enterprises (SGT). The pattern shown above indicates no problems with the assumption that the residuals are normally distributed at each level of the dependent variable and constant in variance across levels of Y.

Table 1: Statistical Significance of the model

\begin{tabular}{|rl|r|r|r|r|r|}
\hline \multicolumn{1}{|l|}{ Model } & Sum of Squares & \multicolumn{1}{c|}{$\mathrm{df}$} & Mean Square & \multicolumn{1}{c|}{$\mathrm{F}$} & \multicolumn{1}{c|}{ Sig. } \\
\hline \multirow{3}{*}{1} & Regression & 20.549 & 3 & 6.850 & .026 & $.040^{\mathrm{b}}$ \\
& Residual & 5441.611 & 21 & 259.124 & & \\
& Total & 5462.160 & 24 & & & \\
\hline
\end{tabular}

a. Dependent Variable: SGT

b. Predictors: (Constant), ICT, ACTC, PWSP

Source: SPSS 20.0 Result Output, 2019

The result of the statistical significance of the model is presented in Table 13. The F-ratio in the ANOVA table above tests whether the overall regression model is a good fit for the data. The table shows that the independent variables statistically significantly predicts the dependent variable $\mathrm{F}(3,21)=0.026, p=0.040^{\mathrm{b}}$ (i.e., the regression model is a good fit of the data). 
Table 2: Model summary

\begin{tabular}{|c|c|c|c|c|c|}
\hline \multicolumn{6}{|c|}{ Model Summary } \\
\hline Model & $R$ & R Square & Adjusted R Square & $\begin{array}{l}\text { Std. Error of the } \\
\text { Estimate }\end{array}$ & Durbin-Watson \\
\hline 1 & $.961^{\mathrm{a}}$ & .834 & .739 & 1.09734 & 2.682 \\
\hline
\end{tabular}

a. Predictors: (Constant), ICT, ACTC, PWSP

b. Dependent Variable: SGT

Source: SPSS 20.0 Result Output, 2019

Table 20 shows the model summary. The coefficient of determination $\mathrm{R}^{2}$ for the study is 0.834 or $83.4 \%$. This indicates that $83.4 \%$ of the variations in the model can be explained by the explanatory variables of the model while $16.6 \%$ of the variation can be attributed to unexplained variation captured by the stochastic term. The Adjusted $\mathrm{R}$ Square and $\mathrm{R}^{2}$ show a negligible penalty $(73.9 \%)$ for the explanatory variables introduced by the researcher. The Durbin Watson statistics is 2.682 shows that there is a minimal degree of negative autocorrelation in the model of the study; hence the estimates of the model can be used for prediction.

Table 3: Regression coefficients

\begin{tabular}{|c|c|c|c|c|c|c|c|c|c|}
\hline \multirow[t]{2}{*}{ Model } & \multicolumn{2}{|c|}{$\begin{array}{l}\text { Unstandardized } \\
\text { Coefficients }\end{array}$} & \multirow{2}{*}{$\begin{array}{c}\begin{array}{c}\text { Standardized } \\
\text { Coefficients }\end{array} \\
\text { Beta }\end{array}$} & \multirow[t]{2}{*}{$t$} & \multirow[t]{2}{*}{ Sig. } & \multicolumn{2}{|c|}{$\begin{array}{l}95.0 \% \text { Confidence } \\
\text { Interval for B }\end{array}$} & \multicolumn{2}{|c|}{$\begin{array}{l}\text { Collinearity } \\
\text { Statistics }\end{array}$} \\
\hline & $B$ & $\begin{array}{l}\text { Std. } \\
\text { Error }\end{array}$ & & & & $\begin{array}{l}\text { Lower } \\
\text { Bound } \\
\end{array}$ & $\begin{array}{l}\text { Upper } \\
\text { Bound } \\
\end{array}$ & Tolerance & VIF \\
\hline (Constant) & 5.117 & 1.566 & & 2.430 & .024 & 6.508 & 83.727 & & \\
\hline 1 АСТC & -.047 & .252 & -.041 & -.187 & .854 & -.571 & .477 & .998 & 1.002 \\
\hline PWSP & .057 & .270 & .046 & .210 & .036 & -.504 & .618 & .995 & 1.005 \\
\hline $\mathrm{ICT}$ & .017 & .312 & .516 & .053 & .023 & -.632 & .665 & .993 & 1.007 \\
\hline
\end{tabular}

a. Dependent Variable: SGT

Source: SPSS 20.0 Result Output, 2019

The result of the multiple regression as shown in Table 15 show that a negative relationship exist between access to credit (ACTC) and Small and Medium Scale Enterprises growth in Benue State Nigeria (SGT) and the relationship is not statistically significant $(p>0.05)$ and not in line with a priori expectation. This means that a unit increases in access to credit (ACTC) will result to a corresponding decrease in the Small and Medium Scale Enterprises growth in Benue State Nigeria (SGT) by margin of $4.1 \%$. Using the probability value of the estimate, $p\left(b_{1}\right)>$ critical value at 0.05 confidence level. Thus, we accept the null hypothesis. That is, we accept that the estimate $b_{1}$ is statistically significant at the $5 \%$ level of significance. This implies that access to credit has no significant effect on Small and Medium Scale Enterprises growth in Benue State Nigeria.

This finding is contrary to that of Bolnick, Bruce and Nelson (1990) who conducted a study in Indonesia to evaluate the impact of credit programs on small enterprises. They found that for those who participated in the credit programs, their production level increased as well as sales. The study found that those borrowers who were able to obtain two loans experienced high growth in profits and household income compared to a control sample, but borrowers who never qualified for the second loan were actually worse off. The negative effect between access to credit on SMEs growth obtained by this study could be as a result of the low level of access to credit by entrepreneurs in the study areas. Also, Dunn (2001) who conducted a study on the impact of micro credit on micro-enterprises in Peru using survey design with a population of 10,000 SMEs, found that program client' enterprises performed better than nonclient enterprises in terms of profit, fixed assets and employment. In Khandker et al. (1998) found that program participation has positive impact on household income, production and employment particularly in rural nonfarm sector and that the growth in selfemployment.

Power supply (PWSP) was positively related to Small and Medium Scale Enterprises Growth in Benue State Nigeria (SGT) and the relationship is statistically significant $(p<0.05)$ and in line with a priori expectation. This means that a unit increases in Power supply (PWSP) will result to a corresponding increase in the Small and Medium Scale Enterprises growth in Benue State Nigeria (SGT) by margin of $4.6 \%$. Using the probability value of the estimate, $p\left(b_{2}\right)<$ critical value at 0.05 confidence level. Thus, we reject the null hypothesis. That is, we accept that the estimate $b_{2}$ is statistically significant at the $5 \%$ level of significance. This implies that Information and Communication Technology has a significant effect on Small and Medium Scale Enterprises growth in Benue State Nigeria.

This finding is in line with that of Mustapha and Abdullahi (2015) who studied the Role of Information and Communication Technology (ICT) in firm productivity in the Developing World. The findings of the study reveal that Information and communication technology (ICT) plays an important role in firm operations such that it becomes indispensable in the contemporary world.

Joint Research Centre (2015) of the European Commission which carried out empirical studies on the impact of ICT activities on SME growth and industry in Europe found that increase in ICT/e-commerce activities over time has led to increase in firm performance. This holds true for both manufacturing and service industries. In contrast, the different types of ICT activities are significantly related to firm productivity. 
A positive relationship exist between Information and Communication Technology (ICT) and Small and Medium Scale Enterprises Growth in Benue State Nigeria (SGT) and the relationship is statistically significant $(p<0.05)$ and in line with a priori expectation. This means that a unit increases in Information and Communication Technology (ICT) will result to a corresponding increase in the Small and Medium Scale Enterprises growth in Benue State Nigeria (SGT) by margin of $51.6 \%$. Using the probability value of the estimate, $p\left(b_{3}\right)<$ critical value at 0.05 confidence level. Thus, we reject the null hypothesis. That is, we accept that the estimate $b_{3}$ is statistically significant at the $5 \%$ level of significance.

This implies that power supply has a significant effect on Small and Medium Scale Enterprises growth in Benue State Nigeria.

The finding of this study is contrary to that of Nyanzu and Adarkwah (2016) who examined the Effect of Power Supply on the performance of Small and Medium Size Enterprises: A comparative analysis between SMEs in Tema and the Northern Part of Ghana and found that Electricity provision in Ghana has been marred by low generation, poor supply and frequent power outages which negatively affected firms performance (profitability).

\subsection{CONCLUSION AND RECOMMENDATIONS \\ Conclusion}

The study investigates the effect of investment climate on Small and Medium Scale Enterprises growth in Benue State Nigeria. This research shows that Small and medium sized enterprises hold a huge promise for Sub Saharan Africa's growth and development. For this growth to be achieved, the climate of investment must be addressed and made favourable for business start-up and growth. While policies and structures are being put in place by many African economies, this study has shown that more is yet to be done. South Africa appears to be on an ascending side of the slope, while economies in West and Central Africa seem to yet be plagued by challenges on different fronts and require urgent policy development and implementation.

Investments and businesses are like crops that must grow on well-watered and fertile land. In view of this, a sustainable environment should be provided for the intending and anticipated businesses and investments. The study indicates that the business environment consists of surrounding factors that either help or hinder the development of businesses. They include the economic and legal environment, the technological environment, the competitive environment, the social environment, and the global environment. The global environment surrounds all other environmental influences. Businesses grow and prosper in a healthy environment. The results are high job growth and the wealth that makes it possible to have a high standard of living and a high quality of life.

Based on factual evidence, the study concluded that there is a significant statistical relationship between power supply and SME growth. Power supply and ICT significantly affects specific firm goals which have far reaching influence on SME growth. Power supply and ICT specifically and significantly influence firm productivity which can induce SME growth.

\subsection{Recommendations}

Based on the findings of the study the following recommendations are made:

i. Small and Medium Scale Enterprises should consciously develop a close relation with financial institutions so as to reduce the incidence of moral hazard or doubts by financial institution but rather gain improved knowledge about the firm which ultimately reduces adverse consideration for a loan which in turn will lead to SMEs growth in the study areas.

ii. Government should as a matter of urgency improve Information and Communication Technology (ICT) access through deliberate policy reforms particularly the National ICT policy such that more entrepreneurs can access ICT facilities affordably and reliably.

iii. Government should effectively regulate the power sector at postprivatization as there are still lingering challenges with billings, tariffs and metering processes. To ameliorate the problem faced by SMEs in the study area, government can create hubs for SMEs in the study area and provide them with adequate electricity or develop renewable energy such as solar energy to improve entrepreneurs' access and growth.

\section{REFERENCE}

[1].Abdullah, M. A. (2000). Small and Medium Enterprises (SMEs): Some pertinent issues. In Abdullah, M. A. \&amp; Bin Bakar, M. I. (eds). Small and medium Enterprises in Asian Pacific countries, (vol. 1). 3-14. New York: Nova Science publishers Inc.

[2].Adeyemi, S. L. (2011). Small and medium scale enterprises as survival strategy for employment generation in Nigeria. Journal of sustainable Development, 4(1), 200-206.

[3].Adom, P. K. (2011). 'Electricity Consumption-Economic Growth Nexus: The African Development Bank (AfDB). 2012. Supporting the Transformation of the Private Sector in Africa: Private sector development strategy of the African Development Bank Group, 2012-2017 (Abidjan).

[4].Ajayi, G. O. (2000). Entrepreneurship Development in Nigeria. Abeokuta, Nigeria; Ajayi Publishing.

[5].Altenburg, T. and Eckhardt, U. (2006). Productivity enhancement and equitable Analysis of the Causal Relationship', Resources and Energy 2, 1979 and applications to technical vocational education and training (TVET) system in Nigeria. Journal of Research and Development, 1(6), 25-35. 
[6].Altenburg, T. and Von Drachenfels, C. (2006). The 'new minimalist approach' to private-sector development: a critical assessment. Development Policy Review 24(4): 387-411.

[7].Arbaugh, J.B., \& Sexton, D.L. (1996).

[8].New firm growth and development: A replication and extension of Reynolds' research. Journal of Enterprising Culture, 4(1):19-36 Armu, M.A. \& Adeyemi, S. A.

[9].(2011).Small and Medium Scale Enterprises as a Survival Strategy for Employment Generation in Nigeria. Journal of Sustainable Development, Canadian Centre of Science and Education.4 (1).200-206.

[10]. Asaju, K. (2010). Vision 20:20:20, Realities and Challenges, in Faculty of Administration Conference Proceedings, ABU Zaria, 1, 162-173.

[11]. Asaolu, T. O., Oladoyin, A. M., \&amp; Oladele, P. O. (2005). A Consideration of the Problems and Prospects of Revitalizing the Small-Scale Sector in Nigeria. European Journal of Scientific Research, 7(3), 5-11.

[12]. Barnes, C. (2011). Microfinance Program Clients and Impact: an assessment of Zambuko Trust Zimbambwe, AIMS project report; USAID, Washington

[13]. Beck, T. \& Cull, R. (2014). Small and medium-sized enterprise finance in Africa. African Growth Initiative (working paper 16). Washington DC: Brookings.

[14]. Beck, T. and Maksimovic, V. (2002). Financial and Legal Constraints to Growth: Does Firm Size Matter? The Journal of Finance LX (1),137-177.

[15]. Bolnick, K., Bruce, T. and Nelson, E. (1990). Evaluating the Impact of Special Credit Program in Indonesia. The Journal of Development Studies, 7(7)61-63.

[16]. Bowen, A., Cochrane, S. and Fankhauser, S. (2012). Climate change, adaptation and economic growth, Climatic Change,

[17]. Springer, vol. 113(2):95-106.

[18]. CBN (2014). Understanding Monetary Policy Series No.43: The Informal Financial Market inNigeria.www.cbn.gov.ng retrieved $31^{\text {st }}$ July, 2017.

[19]. Chaston, I. and Mangles, T. (2017), "Competencies for growth in SME sector manufacturing firms", Journal of Small Business Management, 35(1):32-41.

[20]. Cochrane S. and Fankhauser S. (2012). Climate change, adaptation and economic growth. Climatic Change, 113(2): 95-101.

[21]. De Soto, Hernando, 1990, The Other Path, New York, NY: Harper and Row.

[22]. De Soto, Hernando, 2000, The Mystery of Capital: Why Capitalism Triumphs in the West and Fails Everywhere Else, New York: Basic books.

[23]. Dollar, D., Hallward-Driemeier, M. and Mengistae, T. (2005). Investment Climate and Firm Performance in Developing Economies. Economic Development and Cultural Change, Chicago: University of Chicago Press, pp. 1-7.

[24]. Dunn, E. (2001). Microcredit and Microenterprise Performance: Impact Evidence from Peru. Small Enterprise Development Journal, 12, 22-33.

[25]. Ebaidalla, E. (2014) Youth Unemployment in the Arab World: An Analysis of Causes and Possible Ways Forward. In Naoual Belakhdar, et al. (ed), Arab Revolutions and Beyond: Change and Persistence, Center for North African and Middle Eastern Politics, Freie University Berlin, Berlin., pp. 113-126

[26]. Etuk, R. U., Etuk, G. R., \&amp; Baghebo, M. (2014). Small and medium scale enterprises (SMEs) and Nigeria's Economic Development. Mediterranean Journal of Social Sciences, 5(7):656-662.

[27]. Fjose S., Grunfeld L. A. and Green C.

[28]. (2010). SMEs and growth in subSaharan Africa. Identifying SME roles and obstacles to SME growth. MENON Business Economics Publication no. 14/2010.

[29]. Gans, J.S. and Stern, S., (2000). Incumbency and R\&D incentives: licensing the gale of creative destruction. Journal of Economics and Management Strategy 9 (4), 485-511.

[30]. Goffee, R. and Scase, R. (2015). Proprietorial Control in Family Firms: Some Functions of 'Quasi-Organic' Management Systems, Journal of Management Studies, 22(1):53-68

[31]. Hampel-Milagrosa A., Loewe, M. and Reeg, C. (2015). The entrepreneur makes a difference: evidence on MSE upgrading factors from Egypt, India and the Philippines. World Development 66: 118-130.

[32]. IFC, (2005). Gender Dividend: Growth through Gender Equality, Summary of PREM Week symposium.

[33]. IFC (2007). Annual report 2007: Creating opportunity (English). Washington DC.

[34]. Joint Research Centre (2015), Measuring Entrepreneurship: A Digest of Indicators, OECD-Eurostat Entrepreneurship Indicators Program, OECD, Pari Khandker, S., Knedlik, N. and Shahidur

[35]. R. (1998). Fighting poverty with Microcredit: Experience in Bangladesh, New York: Oxford University Press Klapper, L.

[36]. (2006). Entrepreneurship. Viewp oint: Public Policy for the Private Sector; Note No. 313. World Bank, Washington, DC.

[37]. Klein, K. E. (2006). Funding a new small business? Don't bother with banks. Business Week (Feb10Feb16, 2014):1.

[38]. Klein, M.U. and Hadjimichael. B. (2013). The Private Sector in Development. Entrepreneurship, Regulation, and Competitive Disciplines. Washington, D.C

[39]. Kolvereid, L. (2016). Growth aspirations among Norwegian entrepreneurs. Journal of Business Venturing, 7(3):209-222. 
[40]. Kolvereid, L. and Bullvag, E. (2016). Growth Intentions and Actual Growth: The Impact of Entrepreneurial Choice. Journal of Enterprising Culture (JEC), 4(1):1-17

[41]. Lyons M., Brown A. and Msoka C. (2014). Do micro enterprises benefit from the 'doing business' reforms? The case of streetvending in Tanzania. Urban Studies, 51(8): 1593-1612.

[42]. Masurel, E. and Montfort, K.V. (2016). Life cycle characteristics of small professional service firms. Journal of Small Business Management, 44(3):461- 437 Mills, R. and Fan, Q. (2006). The Investment Climate in PostConflict Situations, World Bank Institute, pp. 78-81.

[43]. Moran, T. (2006). Toward Best Outcomes from Foreign Direct Investment in Poorly Performing States. Journal of Small Business Economy, 14(1): 311-321.

[44]. Muktar, B. G., Gambo, B.A., \&amp; Mukhtar, U. (2015). Consumer preference analysis on local and imported citrus fruit in kano metropolis. Journal of Agricultural Economics, Extension and Rural Development, 3(11), 351-358.

[45]. Mustapha A.I. and Abdullahi, I.F. (2015). Challenges of Entrepreneurship as Perceived by Undergraduate of Tertiary Institutions in Kaduna State.

[46]. National Council of Industry (2001). Proceeding at the 13th National Council Meeting held in Makurdi; Benue State.

[47]. National Council of Industries (2009). ANNUAL REPORT, September 2009.

[48]. Nigerian Institute Of Social And Economic Research (NISER, 2014), Baseline Economic Survey Of Small And Medium

[49]. Scale Industries In Nigeria, National Synthesis Final Report; Survey Of Existing Small And Medium Industries Part (Chapters 1-4),SUBMITTED To Implementation Committee On Baseline Economic Survey Of SMIs In Nigeria.

[50]. Nnanna, O. (2002). The importance of small and medium scale industries in economic development. Bing a Paper Presented at a Workshop on Small and Medium Scale Industries, Equity Investment Scheme, Abuja, Nigeria.

[51]. Nyanzu, F. and Adarkwah, J. (2016). Effect of Power Supply on the performance of Small and Medium Size Enterprises: A comparative analysis between SMEs in Tema and the Northern part of Ghana. Journal of Small Business Management, 12(7):58-70.

[52]. Nzotta, S. M. (2004). Money banking and finance: Theory and practice. Owerri: Jude- Hudson, pp 65-71.

[53]. Oba, U. O., and Onuoha, B. C. (2013). The role of small and medium scale enterprises in poverty reduction in Nigeria: 2001-2011. African research review, an international multidisciplinary journal, Ethiopia 7(4):1-25.

[54]. ODA (2018). Development aid stable in 2018 with more sent to poorest countries, 2018.

[55]. OECD (2004). Promoting entrepreneurship and innovative SMEs in a Global Economy: Towards a more responsible and inclusive globalization. A Report of 2nd OECD Conference of Ministers Responsible for Small and Medium Sized Enterprise (SMEs) in Istanbul, Turkey (3-5 June, 2004).

[56]. Ogechukwu, A. D. (2011). The role of small scale industry in national development in Nigeria. Universal Journal of Management and Social Sciences, 1, 23-41.

[57]. Ogechukwu, A, D., Oboreh, J. S., Umokoro, F., \&amp; Uche, A. V. (2013). Small and medium scale enterprises (SMEs) in Nigeria the Marketing $\quad$ Interface. Global journal of management and Research marketing, 13(9):112

[58]. Okech, C., Walker, E. A. and Redmond, J. (1995). Ownership Motivation and Strategic Planning in Small Business. Journal of Asia Entrepreneurship and Sustainability, 11(4):71-78.

[59]. Okonkwo, N. O., \&amp; Obidike, C. P. (2016). Small and medium scale enterprises financing in Nigeria: Problems and prospects. International journal of innovative sciences and Humanities Research, 4(1):77-86.

[60]. Okpara, J. O. (2011). Factors constraining the growth and survival of small and medium enterprises in Nigeria: implication for poverty alleviation. Management Research Review, 34(2), $156-171$. DOI:10.1108/01409171111102786.

[61]. Olabisi, S. Y., Olagbemi, A. A., \&amp; Atere, A. A. (2011). Factors affecting small-scale business performance in informal economy in Lagos State-Nigeria: A gender based analysis. Retrieved October 2016, from: http://www.ilo.org.public/english/ iira/documents/congree/regional/1 agos2011/5thsession/session5a/s mallscaleent.pdf.

[62]. Osotimehin, K. O., Jegede, C. A., Akinlabi, B. H., \&amp; Olajide, O. T. (2012). An evaluation of the challenges and prospect of micro and small scale enterprises development in Nigeria. American Journal of Contemporary Research, 2(4), 174-185.

[63]. Owualah, S. I. \& Obokoh, L. O. (2008). Tackling youth restiveness in the Niger Delta Region of Nigeria through entrepreneurship, Journal of Enterprising Communities: People and Places in the Global Economy, 2(2), 168-179

[64]. Palmade, V and Anayiotos, A, (2005). Rising Informality. Policy for the Private Sector: Note 298. Washington: The World Bank.

[65]. Runyan R. C. (2006). Small Businesses in the face of crisis: identifying barriers to recovery from a natural disaster. Journal of Contingencies and Crisis Management 14 (1): 12-26.

[66]. Shimer, R. (2012). Reassessing the ins and outs of unemployment, Review of Economic Dynamics, 15(2):127-148.

[67]. Solomon, G. (2011). Building small and medium scale enterprises: A strategy for economic development in Nigeria. Jos Journal of Economics, 4(1), 130152.

[68]. Taiwo, J. N., Falohun, T. O. (2016). SMEs financing and its effects on Nigerian economic growth. European Journal of Business Economics and Accounting, 4(4), 37-54. 
[69]. The World Bank, (2005). World Development Report 2005: A Better Investment Climate for Everyone”, World Bank. http://siteresources.worldbank.org/INTWDR2005/Resources/03_W DR_PO1_Ch01.pdf

[70]. USAID, (2015). Nigeria: Economic Performance Assessment: Nathan Associates.

[71]. World Bank. (2002). Review of Small Business Activities. Washington, DC: World Bank World Bank, (2005). World Development Report 2005: A Better Investment Climate for Everyone", World Bank http://siteresources.worldbank.org/INTWDR2005

[72]. World Bank, (2007). Gender and Economic Growth in Kenya: Unleashing the Power of Women, Directions in Development. World Bank, Washington, DC.

[73]. World Development Report (2005): A Better Investment Climate for Everyone - Summary (Russian). World Development Report. 